\title{
Na pancada do ganzá e a racionalização da música ocidental ${ }^{1}$
}

\author{
Maurício Hoelz Veiga Júnior ${ }^{2}$
}

\section{Racionalizações}

Ao início d'A ética protestante e o espírito do capitalismo, Max Weber delimita a tarefa de sua investigação afirmando que "um filho" do moderno mundo cultural europeu, ao lidar com problemas da história universal, não poderia deixar de perguntar pelo encadeamento de fatores que conduziram ao surgimento de fenômenos culturais, dotados de sentido e validade universais. Tal qualidade universal dos fenômenos culturais parece, ironicamente, reforçar o próprio questionamento desta universalidade como valor cultural. O sociólogo alemão mostra-se surpreso diante do enigma de seu próprio mundo. Desde o início, Weber parece duvidar que o universalismo seja uma qualidade intrínseca aos fenômenos do Ocidente; antes de mais nada, a suposta ideia de universalismo seria um valor cultural central e constitutivo da individualidade histórica que é o capitalismo ocidental moderno. A surpresa de Weber não se circunscreve à suposta universalidade, mas abarca também a racionalidade, entendida como adequação de meios a fins. Por que só no Ocidente a mesma irrompe com toda pujança, atingindo as diversas esferas da vida, incluindo a talvez mais hermética delas, a música?

Por que (devido a que condições sociais), embora outras culturas tenham um ouvido muito mais refinado e uma vida musical muito mais intensa, a música

\footnotetext{
${ }^{1}$ Este mesmo texto e com mesmo título está disponibilizado no portal da ANPOCS, no repositório de comunicações apresentadas em um Congresso que exige o envio do trabalho completo de todos os participantes. Neste portal da ANPOCS o texto é considerado, pelos critérios de avaliação da CAPES, como anais de eventos e não como uma publicação acadêmica. (Esclarecimento do autor)

${ }^{2}$ Doutorando em Sociologia no Programa de Pós-Graduação em Sociologia e Antropologia da Universidade Federal do Rio de Janeiro (PPGSA/UFRJ)
}

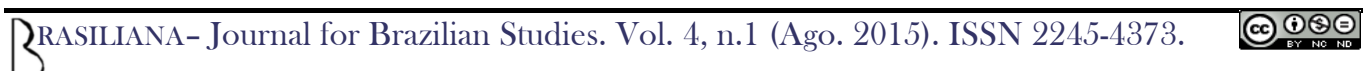


harmônico-tonal só se desenvolveu na Europa e numa determinada época, enquanto em outras partes a racionalização da música empreendeu um caminho bem diferente, frequentemente oposto? Weber lançará mão do método comparativo a fim de evidenciar a particularidade deste desenvolvimento histórico em face da multiplicidade de possibilidades de racionalização, entendida como processo de longa duração passível de assumir sentidos, intensidades e direções muito diferentes, e mesmo contraditórias (Waizbort, 2008, p. 55).

Em seu escrito inacabado, intitulado Fundamentos racionais e sociológicos da música (1995), Weber aponta que os "fatos fundamentais" de desenvolvimento dos sistemas sonoros (e também de tensão no interior deles) e de racionalização da música são a assimetria da divisão da oitava - problema de natureza lógica que emerge do fato de que o intervalo de oitava só é dividido em frações próprias nos intervalos de quarta e quinta, e evidenciado pela necessidade de transposição da melodia -; e o problema físico (logo, de natureza técnica) dos ciclos de intervalos e da racionalização harmônica do material sonoro (a "desafinação natural" do som) - já que os ciclos de quinta, de quartas ou de qualquer outro intervalo determinado racionalmente nunca se encontram exatamente, isto é, não apresentam sons musicais com frequências idênticas; em outras palavras, se o cálculo não quadra perfeitamente, haverá sempre um resto, a chamada "coma pitagórica". As diversas culturas musicais desenvolverão de modo contingente sistemas sonoros que trazem soluções distintas historicamente para esses problemas. Portanto, e este é o ponto que gostaria de enfatizar, para Weber, não há uma única e mesma racionalidade, e a música, assim como as demais dimensões da vida social, pode ser racionalizada em direções e intensidades diversas. Tal processo é eminentemente contingente e o seu sentido diferencial, específico para cada singularidade histórica, é o 
que interessa ao sociólogo compreender. ${ }^{3}$ Por meio de uma análise comparativa do desenvolvimento de diferentes culturas musicais, Weber aponta como especificidade da racionalidade que opera no sistema sonoro do Ocidente o uso da quinta justa, interpretado harmonicamente, como intervalo fundamental para a divisão da oitava, que levará por sua vez, com a divisão harmônica da quinta nos intervalos de terças maior e menor, à identificação do intervalo de quarta como dissonância. Conforme discute Weber, a tentativa de equacionar esse problema lógico levará ao desdobramento do princípio da divisão melódica (distância) e do princípio da divisão harmônica dos intervalos. Por outro lado, o temperamento moderno será o sistema de afinação que permitirá resolver o problema técnico da "irracionalidade" dos ciclos de intervalos, ao igualar 7 oitavas com 12 quintas justas e dividir o âmbito sonoro da oitava em 12 semitons de mesmo tamanho. Foram os instrumentos que se constituíram, nos termos do autor, nos portadores da racionalização desses intervalos, operando sua abstração e organização sequencial nas escalas.

Não é possível nem desejável reconstruir aqui toda a intrincada argumentação weberiana. Tendo em vista nosso propósito, interessa destacar dois desenvolvimentos decisivos para o sentido pelo qual se orientou a racionalização do sistema tonal. Primeiro, a notação mensural, que permite a previsão, o cálculo e a coordenação das diversas vozes, desencadeando assim o declínio das ornamentações improvisadas e a

\footnotetext{
${ }^{3}$ Vale notar que esta perspectiva de Weber exprimia uma crítica à musicologia positivista contemporânea. Fundada na crença em uma natureza ordenada, cujas leis deveriam ser reveladas pela ciência por meio das suas relações de causa-efeito, essa corrente musicológica sustentava que a racionalidade era intrínseca ao fenômeno musical, o que a levava a assumir teleologicamente o sistema tonal moderno como o estágio mais avançado de desenvolvimento técnico do princípio tonal de organização sonora. Rezende observa que a obra de Weber se apoiava "nas investigações empíricas da musicologia comparada e no diagnóstico da falência da concepção ilustrada do progresso unívoco através da ciência e da razão. Desse modo, o sociólogo se opõe às perspectivas últimas das obras que se irmanam na crença em uma racionalidade que organiza e orienta o curso do desenvolvimento dos fenômenos do mundo empírico, e que acabam por conceber as relações musicais como um contínuo movimento de realização dessa racionalidade, seja ele dialético ou não. Por detrás da aparência de unicidade, diria Weber, esse sistema esconde contradições, conflitos e irracionalidades" (Rezende, 2010, p. 101).
} 
suplantação completa da tradição oral. Segundo, o sistema temperado, o qual implicou, segundo Weber, o apagamento completo das diferenças entre as tonalidades, a redução da variedade dos modos tonais e, com isso, o embrutecimento da sensibilidade melódica. O racionalismo ocidental encontrou no temperamento igual a solução prática mais racional para o problema dos restos, das irracionalidades que subsistem em qualquer tentativa de racionalização dos intervalos com base em uma afinação pura: desafinar ligeiramente todos os intervalos e assim obter doze semitons iguais. Weber via o piano como o portador por excelência do novo sistema musical, sintetizando em si tanto o princípio do contraponto quanto o da harmonia. Não à toa passou a ser o principal instrumento para os compositores e o centro de gravitação da orquestra, que ele encerra em si virtualmente. Com a universalização de uma educação harmônica baseada no piano, o sistema tonal moderno também tende a se tornar universal. E essa universalidade do sistema tonal, impulsionada pela disseminação em massa do piano, é, segundo o sociólogo alemão, indissociável do "impulso mais irresistível da vida moderna": o capitalismo. O custo cobrado por essa universalização não escapa a Weber: ela retirou de nossos ouvidos a delicadeza que estava na base do refinamento melódico de várias culturas musicais não-ocidentais. $O$ texto inacabado de Weber termina por demonstrar que o sistema harmônico-tonal ocidental dificilmente poderia ser visto como um sistema completo, lógico e fechado (Fuente, 2011).

Em seu clássico Viena fin-de-siècle, o historiador Carl Schorske ressalta como o sistema tonal estava fundado, desde a Renascença, numa organização hierárquica dos sons (a escala diatônica), agrupados em forma de tríades e de acordes que eram usados em encadeamentos harmônicos por meio dos quais funcionava o jogo entre tensão e repouso, equilíbrio e movimento, garantindo o sentido de direção da música - aquela sensação de começo, meio e fim, claramente definida. A tríade tônica constituía o elemento de autoridade, estabilidade e, sobretudo, repouso. No entanto, pondera o 
autor, "música é movimento; se a consonância é tida apenas como um quadro em repouso, todo movimento será dissonante" (Schorske, 1988, p. 234). Nesse sistema musical o movimento estava rigidamente subordinado à tonalidade, de modo que todo movimento surgia da tríade tônica e voltava a ela. A dissonância era legitimada enquanto elemento dinâmico - partindo do contexto da tonalidade -, na medida em que tinha sempre que se referir a esta. Cabia ao compositor manipulá-la no interesse da consonância, "como um líder político num sistema institucional que manipula o movimento, canalizando-o para servir aos propósitos da autoridade estabelecida" (ibidem). A passagem de uma a outra tonalidade facultada pelo emprego da modulação era "um momento de ilegitimidade permitida, um estado acentuado de ambigüidade, a ser resolvido por uma nova orientação numa nova modalidade, ou pelo retorno a uma anterior" (ibidem). Schorske enfatiza ainda que a tonalidade na música integrava o mesmo sistema sócio-cultural que a ciência da perspectiva na pintura, com seu foco centralizado, e o jardim geométrico, como extensão da arquitetura racional sobre a natureza: o sistema barroco do status na sociedade e do absolutismo constitucional na política. Não fortuitamente foi Rameau, o músico de corte de Luís XV, o teórico mais inflexível das "leis" da harmonia. Uma vez que "o sistema tonal era uma organização musical onde os tons tinham um poder desigual para expressar, validar e tornar suportável a vida do homem numa cultura hierárquica racionalmente organizada" (Ibidem), a harmonia clássica na teoria e na prática tinha por objetivo fazer com que todo o movimento ao final recaísse dentro da ordem, da "cadência".

No entanto, o século XIX promove aos poucos a expansão da dissonância e a erosão da tonalidade fixada, centro da ordem tonal:

Na música e em outros setores, o tempo avançou sobre a eternidade, a dinâmica sobre a estática, a democracia sobre a hierarquia, o sentimento 
sobre a razão. [...] Os tons cromáticos - os semitons - têm todos um único valor, e constituem um universo de sons igualitário. Para alguém acostumado à ordem hierárquica da tonalidade, tal democracia é perturbadora. É a linguagem do fluxo, da dissolução. Da liberdade ou da morte, dependendo do ponto de vista (Schorske, 1988, p. 324).

Assim, essas transformações na linguagem musical identificadas por Schorske figuravam uma profunda rejeição aos méritos propalados do autocontrole racional. Nesse sentido, por exemplo, assim como as teorias de Freud sobre as forças irracionais do inconsciente, os experimentos de Schoenberg com o atonalismo, dentro do modernismo musical vienense, colocam em questão a capacidade do homem de ordenar racionalmente o mundo. Mais do que isso, a ruptura com a tonalidade significava um desafio para a ordem (social, política e cultural) que ela representa.

\section{Por entre as barras do compasso}

Essas reações de descentramento do paradigma da música ocidental tiveram na valorização das músicas de culturas "primitivas", "tradicionais" e não-ocidentais uma de seus principais fontes, a exemplo do encontro de Debussy com a orquestra de gamelão javanesa, seu sistema tonal não-diatônico e seu modelo significativo de complexidade rítmica. Para Debussy, a música do Leste representou uma alternativa ao romantismo wagneriano e ao cromatismo. Em obras como Prélude à l'après-midi d'un faune, células melódicas curtas e o uso da escala de tom inteiro substituiu a necessidade por um centro tonal, e procedimentos polimétricos e polirrítmicos suplantaram o sentido tradicional de tempo e ritmo. $\mathrm{O}$ chamado primitivismo estético, que atraia o interesse das vanguardas artísticas européias como meio de revitalização de uma longa 
tradição estética vista como decadente, no caso do modernismo brasileiro encontrava-se não em lugares distantes e exóticos, mas em nossa sensibilidade, o que abria uma produtiva frente de exploração das afinidades vistas entre o "primitivo", valorizado pelas vanguardas européias, e o "popular" no Brasil. Se esse interesse pelo "primitivo" não explica inteiramente o programa de abrasileiramento do Brasil de nossos modernistas, em particular o de Mário de Andrade, é preciso reconhecer que "facilitou muito a valorização do nosso passado e das nossas manifestações artísticas populares e eruditas, até então vistas com preconceito, como se fossem expressão do nosso atraso ou inferioridade em relação à arte européia" (Botelho, 2012, p. 43).

Tal valorização da cultura e das práticas populares, no caso de Mário de Andrade, não se esgota numa preocupação ontológica (em verdade presente, mas incapaz de conferir sentido geral à sua obra), confinável ao nível programáticoapologético do seu tão propalado nacionalismo. A obsessão de Mário pela cultura popular - vazada no cantador de cocos Chico Antonio como uma espécie de personagem-síntese -seria mais a expressão do dilaceramento e da percepção da sociedade "em suas tensões sísmicas não-aparentes do que de um feliz arranjo de classes e raças que se acomodariam harmonicamente para sanar a falta de 'caráter' nacional", como defende Wisnik (1979, p. 46). Este analista lembra-nos ainda da dificuldade mais geral, na obra de Mário de Andrade, em passar da tensão à resolução, da dissonância à consonância, que resulta num regime textual marcado pela tensão contínua, pelo dilaceramento e mesmo pela impossibilidade estética da resolução (ibidem). Se tomarmos, por exemplo, o Ensaio sobre a música brasileira (1928), obra comumente identificada pela fortuna crítica como principal peça de rotinização do projeto nacionalista de Mário, poderemos surpreender nela uma concepção sofisticada da constituição da identidade como processo eminentemente relacional, que nega que a representação do colonizado seja uma questão de gradiente de autenticidade e 
complexidade, ao instaurar certo hibridismo no seio da identidade que se constrói nas fissuras e nas negociações que articulam o interno e o externo. Senão vejamos.

No Ensaio, Mário pondera que os modernos, ciosos da curiosidade exterior de muitos dos nossos documentos populares confundem o destino da música brasileira com seu próprio prazer diletante e individualista, e defendem não o patrimônio nacional, como pretendem, mas o exotismo - "vatapá, jacaré, vitória-régia" (Andrade, 1972, p. 14). Segundo o autor, contribui para esta "falsificação da entidade brasileira" outro elemento importante: “opinião de europeu”. Assim, “o diletantismo que pede música só nossa está fortificado pelo que é bem nosso e consegue o aplauso estrangeiro" (Ibidem), exemplo lapidar seria o caso de Villa-Lobos, no qual se poderia facilmente perceber o "coeficiente guassú" com que o exotismo concorreu para o sucesso do artista. Para Mário, potenciar ainda mais esse coeficiente guassú com a valorização do nosso exotismo não favorecia a autonomização da arte brasileira como supunham, mas, antes, atualizava nossa condição colonial.

A Europa completada e organizada num estádio de civilização, campeia elementos estranhos para se libertar de si mesma. Como a gente não tem grandeza social nenhuma que nos imponha ao Velho Mundo, nem filosófica que nem a Ásia, nem econômica que nem a América do Norte, o que a Europa tira da gente são elementos de exposição universal: exotismo divertido. Na música, mesmo os europeus que visitam a gente perseveram nessa procura do esquisito apimentado. Se escutam um batuque brabo muito que bem, estão gozando, porém se é modinha sem síncopa ou certas efusões líricas dos tanguinhos de Marcelo Tupinambá, isso é musica italiana! Falam de cara enjoada. E os que são sabidos se metem criticando e aconselhando, o que é perigo vasto. Numa toada, 
num acalanto, num abôio desentocam a cada passo frases francesas, russas, escandinavas. Às vezes especificam que é Rossini, que é Boris. Ora, o quê que tem a Musica Brasileira com isso! Se Milk parece com Milch, as palavras deixam de ser uma inglesa outra alemã? O que a gente pode mais é constatar que ambas vieram dum tronco só. Ninguém não lembra de atacar a italianidade de Rossini porque tal frase dele coincide com outra da ópera-cômica francesa (Andrade, 1972, p. 14-15).

Outra variante deste nacionalismo narcísico se verifica na defesa de nossos traços ameríndios como distintivos do caráter nacional. Vale citar o raciocínio perspicaz e não menos irônico de Mário, que expõe o (e ao) ridículo ao confrontar com o absurdo: “Se fosse nacional só o que é ameríndio, também os italianos não podiam empregar o órgão que é egípcio, o violino que é árabe, o cantochão que é greco-hebraico, a polifonia que é nórdica, anglo-saxônica flamenga e o diabo. Os franceses não podiam usar a ópera que é italiana e muito menos a forma-de-sonata que é alemã. E como todos os povos da Europa são produto de migrações pré-históricas se conclui que não existe arte européia..." (Andrade, 1972, p. 16). Pode-se dizer que esse raciocínio, ao demonstrar o infundado de hierarquias como a de que a "cópia" é secundária em relação ao "original", depende dele, vale menos etc., conduz ao próprio questionamento do primado da origem que está na base das concepções mais convencionais de identidade. Não obstante o alívio que a solução pudesse proporcionar ao amor-próprio e também à inquietação de um país assolado por uma epidemia de "moléstia de Nabuco", Mário, como se vê, não cai na ilusão simplória e inversa de supor que a não reprodução da tendência européia, mesmo que já desvestida de seu prestígio de originalidade, poderia nos dar uma vida intelectual mais substantiva, com um fundo nacional genuíno, não adulterado. 
Segundo Mário, seria preciso reconhecer a diversidade de fontes da música brasileira: ameríndia (em porcentagem pequena), africana, portuguesa, a influência espanhola (sobretudo a hispano-americana do Atlântico - Cuba e Montevidéu, habanera e tango) e a europeia, pelas danças (valsa, polca, mazurca) e na formação da modinha. Se o artista deveria selecionar a documentação que lhe serviria de estudo ou de base, por outro lado não deveria cair num "exclusivismo reacionário que é pelo menos inútil" (Andrade, 1972, p. 26). Mário propõe que “a reação contra o que é estrangeiro deve ser feita espertalhonamente pela deformação e adaptação dele. Não pela repulsa" (ibidem). ${ }^{4}$ Se seria "preconceito útil" preferir o que já é caracteristicamente brasileiro, seria "preconceito prejudicial repudiar como estrangeiro o documento não apresentando um grau objetivamente reconhecível de brasilidade" (ibidem). O artista não deve ser nem exclusivista nem unilateral, mas se beneficiar da diversidade e da diferença, sustenta. Essa ressignificação do elemento europeu pode ser vista quando Mário discute a instrumentação, no exemplo da "orquestrinha". Nela o fato de a maioria dos instrumentos serem importados não impede que tenham assumido até como solistas caráter nacional. Mário relata que, numa fazenda localizada em zona que permaneceu especificamente caipira, teve ocasião de escutar uma "orquestrinha" de instrumentos feitos pelos próprios colonos. "Dominavam no solo um violino e um violoncelo... bem nacionais. Eram instrumentos toscos não tem dúvida mas possuindo uma timbração curiosa meia nasal meia rachada, cujo caracter é fisiologicamente brasileiro" (Andrade, 1972, p. 55). Timbre anasalado emoliente, de rachado discreto, longe do "efeito tenorista

\footnotetext{
${ }^{4}$ Exemplo desse procedimento pode ser visto na poética de Paulicéia Desvairada (1922), primeiro livro de poesias no Brasil a difundir os princípios estéticos das vanguardas européias, além de sistematizar o uso do verso livre. Como sustenta Lopez, nele começa a se estruturar o trabalho de digerir e transformar, visando à adequação verdadeiro crivo crítico que seleciona -, verificando a convivência das variadíssimas propostas das vanguardas européias (Lopez, 1996: 18). A filtragem converte a influência em perspectiva crítica de criação. Não à toa, o "Arlequim" seria o motivo que organiza esteticamente o livro e a colagem, a forma que trabalha estruturalmente na poesia as costuras do arlequim.
}

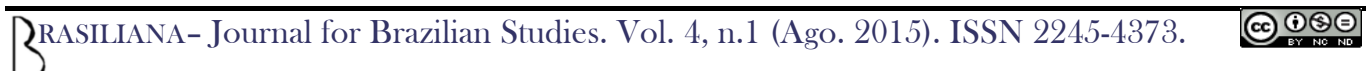


italiano ou da fatalidade prosódica do francês" (Ibidem). No entanto, "é perfeitamente ridículo a gente chamar essa peculiaridade da voz nacional, de falsa, de feia, só porque não concorda com a claridade tradicional da timbração européia". Afinal, "Ser diferente não implica feiúra. Tanto mais que o desenvolvimento artístico disso pelo cultivo pode fazer maravilhas. Da lira de 4 cordas dos rapsodos primitivos a Grécia fez as 15 cordas da citara. Do santir oriental e do cimbalon húngaro que Lenau inda cantou, ao piano de agora, que distância através de todas as variantes de clavicórdios! Da escureza e dos erres arranhentos da fala dele o francês criou uma escola de canto magnífica" (Ibidem). Não se trata nem de advogar "regionalismos curtos" nem de permanecer "embebedados pela cultura européia", mas de perceber que os elementos nacionais sedimentados poderiam se enriquecer pelo contato com o estrangeiro. Neste movimento Mário concede direito à diferença e valoriza uma certa capacidade de diferenciar sem hierarquizar. As hierarquias que decerto existem devem ser detectadas pelo olhar, mas não por ele projetadas. Além disso, parece negar uma visão historicista do tempo, em que este seria percebido como um processo linear, evolutivo e progressivo, articulando eventos numa lógica de causa e conseqüência, e a realidade, por sua vez, passaria a ser vista como uma totalidade coerente e ordenada.

Nesse contexto de transformações mais amplas na linguagem musical e de grande impregnação teórica, de pesquisa sobre a criação popular e busca de uma solução brasileira para a música ganha inteligibilidade o trabalho sistemático e metódico de Mário de Andrade sobre o folclore musical nordestino - que daria corpo à obra de fôlego inacabada Na pancada do ganzá, a qual seria composta de quatro livros, Danças Dramáticas do Brasil, Melodias do Boi e outras peças, Os Cocos e Música de Feitiçaria no Brasil (todos organizados e publicados postumamente por Oneyda Alvarenga), além de manuscritos com análises teóricas sobre esses elementos musicais (Teixeira, 2007; Toni, 
2008). ${ }^{5}$ De modo geral, esta empreitada revela, a partir da análise dos processos de criação da música popular, uma visão crítica do sentido assumido pelo processo de racionalização (nas diferentes esferas culturais) no Ocidente moderno. Impossibilitada de se movimentar dentro de um estilo importado, a imaginação popular brasileira, evitando a subserviência da cópia, adotou uma solução peculiar de adaptação "espertalhona" das formas populares européias, cujo sentido profundo correspondia a outras realidades sociais e históricas. Assim, Mário reivindica fortemente a valorização do folclore e das práticas culturais populares como meio estratégico de abrasileiramento da cultura erudita produzida no Brasil, procurando esvaziar a distinção entre cultura erudita e popular em favor da promoção do diálogo criativo entre elas. É nesse sentido, por exemplo, que se pode entender o fascínio do poeta pelas "invenções" "luminosas" e "surrealistas" do cantador de cocos nordestino, que, em geral, interpreta uma partitura invisível, que a "boca geral" vai escrevendo aos poucos: ele não possui a veleidade do criador de obras originais e não está sujeito à fratura entre subjetividade e cultura, afinal sua atividade consiste em transmitir a criação de um autor sem nome, que é ele próprio e, ao mesmo tempo, o ultrapassa. O cantador também não é um típico intérprete, já que a própria separação entre criar e interpretar lhe é desconhecida. Ademais, não precisa escolher entre alternativas de interpretação, pois na música popular cada peça criada, mesmo quando nunca antes ouvida, é fiel a uma tradição que antecede qualquer peça em particular (Travassos, 1997). Sem texto obrigatório nem entrecho determinado, com quebra das regularidades rítmicas e métricas por meio da interpolação de refrões curtos,

\footnotetext{
${ }^{5}$ Essa guinada "etnográfica" de Mário para a cultura popular envolve fundamentalmente as viagens ao Norte em 1927 e ao Nordeste em 1928-1929, nas quais respectivamente estuda as festas populares do meio do ano e trabalha na coleta de documentos musicais do populário, além de conhecer o cantador de cocos potiguar Chico Antonio. Desde a época da colheita de melodias no Nordeste até 1933, Mário se dedicou a passar a limpo e ordenar os resultados das pesquisas e munir-se de ampla leitura sistemática para estudá-los, registrada numa "Bibliografia" de trabalho iniciada em 23 de agosto de 1929. Os escritos para o Na pancada do ganzá só começaram em 1934 e aqueles existentes devem ter sido elaborados em 1934-1935 (Alvarenga, 1974).
}

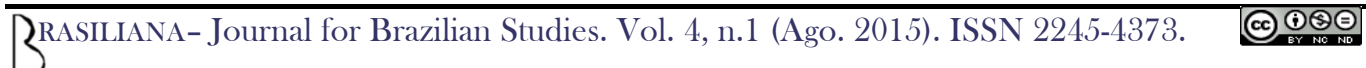


com emprego comum da variação e da dialogação entre solista e coro, os cocos, para Mário, tem caráter eminentemente improvisatório: neles observa-se uma libertação muito maior em relação à fórmula do compasso, se comparados inclusive a nossas danças populares, como o maxixe, o cateretê e o samba. Nos cocos, não há conflito entre ritmo e compasso, pois o primeiro é livre e prescinde do esquema métrico do segundo (Andrade, 1984, p. 367). Esplende, assim, a dificuldade de adequação desses cantares à quadratura do compasso. Diz Mário: “Momentos há em que se torna quase impossível descobrir e grafar com exatidão não só pequenas figurações pequenas 'fitas' virtuosísticas episódicas como até o ritmo geral da peça" (Andrade, 1984, p. 365). Opondo-se à binaridade obrigatória na rítmica brasileira, Mário sustenta que o compasso unário tenta ser mais fiel à acentuação prosódica dos cocos. A frase verbal que determina o período também determina o compasso, porém a fala cotidiana não reconhece e não se encaixa nas regras da música escrita, de modo que a partitura do cantador torna-se irregular. Ao abolir o paradigma métrico, Mário de Andrade nos propõe esquecer a concepção tradicional de compasso e adotar unidades mais variadas de tempo, que acompanhariam acentuações também mais suaves e menos simétricas em sua periodicidade.

Pela maneira com que escutei cantar pessoas acostumadas ao jeito dos coqueiros, o que me parece é que pra estes a música tem um caráter improvisante sempre. Gente que ignora a teoria musical, compasso, ritmo (...). Não cogitam disso e, quando cantam, o que sai é um verdadeiro recitativo musical, "ad libitum", a que normaliza ritmicamente apenas a fatalidade fisiológica do ser. E isso é de fato a maneira mais humana e mais verdadeira de conceber o ritmo (Andrade, 1984, p. 367). 
Dança, dinamogenia e recitativo articulam-se na arte do cantador, independente da sistematização racional-simétrica da escrita ocidental: “O cantador aceita a medida rítmica justa sob todos os pontos-de-vista a que a gente chama de Tempo mas despreza a medida injusta (puro preconceito teórico as mais das vezes) chamada compasso. E pela adição de tempos, talequal fizeram os gregos na maravilhosa criação rítmica deles, e não por subdivisão que nem fizeram os europeus ocidentais com o compasso, o cantador vai seguindo livremente, inventando movimentos essencialmente melódicos" (Andrade, 1972, p. 36).

A transgressão de compasso também era divisada por Mário nos cultos religiosos de transe e encantamento, que libertavam o cantador da divisão rítmica, num contexto em que, como nos lembra Monteiro (2014, mimeo) o discurso civilizado alertava para a necessidade de dar compasso aos ritmos perigosos desse mesmo transe. Mário passou a nomear emblematicamente a sujeição à quadratura rítmica de "falsa dinâmica do compasso", mostrando, de diferentes maneiras, a arbitrariedade inescapável de qualquer tentativa de determinação de um compasso único e exato para as rezas cantadas. Lembra-nos que "feitiçaria e música sempre andaram fundidas uma na outra" (Andrade, s/d: 25) e que, através do ritmo, a música canalizaria sua força dinamogênica, hipnótica e sugestionadora, capaz de atuar sobre o físico, "entorpecendo, dionisiando, tanto conseguindo nos colocar em estados largados de corpo fraco e espírito cismarento, como nos violentos estados fúria" (Andrade, s/d, p. 39). Nesse sentido, nosso autor distingue três tipos de agência rítmica na música de feitiçaria brasileira. Nas feitiçarias de origem africana, predomina a violência do ritmo rebatido, em geral em peças de eminente caráter coreográfico acompanhadas de dança - a qual colabora para o efeito entorpecente -, com a repetição excessiva de um pequeno motivo rítmico provocando obsessão. Já no catimbó, as melodias - chamadas de "linhas", e não de "pontos" como 
na macumba - raramente apresentam dança e são de rítmica muito livre, "legítimos recitativos" (idem, p. 41). Esses ritmos livres, acrescenta Mário, “de andamento lerdo, são eminentemente dubitativos, por assim dizer, deixam o ser eminentemente indeciso, vago, cismarento - o que concorda mais com o estado psíquico propício às manifestações do baixo espiritismo" (idem, p. 41-42). Há ainda peças construídas em ritmo livre, porém incisivo, como o famoso canto de Xangô da macumba carioca, celebrizado na versão de Villa-Lobos. Um flautista afamado, que já fora ogã de macumba, teria contado a Mário que “às vezes uma pessoa na qual o santo entrou, fica de tal forma possessa que puxa um canto novo. Um canto que ele pelejava pra acompanhar com as batidas do tambor e de que era impossível escrever o compasso" (idem, p. 42, grifos no original). Entre o ritmo rebatido e o ritmo livre, Mário de Andrade distingue ainda um terceiro processo hipnótico de ritmar as melodias, frequente nas peças coreográficas rurais, e que consiste em introduzir episodicamente, no decorrer duma linha fortemente ritmada (por exemplo, num dois-por-quatro durante oito compassos), pequenos acréscimos de tempo, em geral um tempo, deslocando assim os acentos e o compasso.

É justo que as grafemos em binário porque a binaridade é evidente pelos acentos e pela quadratura dos compassos, mas o homem do povo, não usa o defeituoso processo nosso do compasso que nos faz partir do múltiplo prá unidade. Ele utiliza o sábio e lógico princípio de partir da unidade pro múltiplo, como os Gregos, o que lhe permite uma riqueza rítmica enorme. Se ele tem uma palavra a mais, se carece respirar, se lhe vem uma fantasia melódica, ele simplesmente diz a palavra, respira ou vocaliza como quer, acrescentando mais um tempo e deslocando o acento. Na verdade o compasso único legítimo de que o nosso povo se 
serve nas suas peças de caráter coreográfico, é o compasso unário (idem, p. 43).

Exemplo notável dessa liberdade rítmica, que torna a linha oscilante e desnorteadora, é dado, segundo o autor, pelo ponto de Ogum, construído numa rítmica fugidia em que a uma série de dois compassos ternários segue-se sempre um compasso binário. Nosso povo utilizaria ainda um "processo curiosíssimo, verdadeiro compromisso rítmicotonal": fazer com que o ritmo não acabe ao mesmo tempo que a evolução tonal da melodia, o que faz com que a peça seja recomeçada a fim de que a melodia acabe tonalmente, de modo que "se pode dizer que o povo brasileiro já inventou o moto contínuo...". ${ }^{6} \mathrm{O}$ ponto de Ogum emprega, além disso, o princípio da variação, tal como usado pelos cantadores do Brasil inteiro, sobretudo nos cocos de embolada no Nordeste. Esse processo - derivado segundo Mário das falhas de memorização, mas sistematicamente praticado - consiste em, na repetição (de um motivo ou frase) da melodia, modificar-lhe dois ou três sons, ou deslocar algum acento em virtude das acentuações das palavras no texto. Constitui, portanto, a contínua modulação diferida dos modelos.

\footnotetext{
${ }^{6}$ Desenvolve Mário de Andrade: "Explico bem; sobre um texto dado, se fixou um ritmo de ordem exclusivamente musical, que consiste na repetição geralmente de um, ou mais motivos rítmicos. Esta repetição agrupada pelos acentos fixa a binaridade e a quadratura estrófica da melodia. Assim, quando o texto chega ao seu ponto final, o ritmo da melodia também chegou ao seu ponto final. Isso dá a sensação de repouso, que não apenas permite, mas provoca a terminação da cantoria. Mas sucedeu que a evolução harmônica da melodia, ao finalizarem texto e ritmo, não está na tríade tonal, mas numa das notas de passagem da escala, evocando pois um acorde dissonante. Se a melodia também estivesse na tônica ou na mediante, a sensação de repouso, de fim, seria completa, e levaria a finalizar a repetição. Mas o que a psique nacional deseja é mesmo a repetição, a repetição inumerável que hipnotiza ou embebeda, e por isso a melodia, ao chegar o ponto final de texto e ritmo, está na sensível, no segundo grau, no quarto, em geral provocando justamente o acorde de sétima-de-dominante, que obriga a continuar pelo menos com mais um som. Mas pra que este som seja executado, foi preciso reiniciar o texto e reiniciar o ritmo, e reiniciados estes é imprescindível ir até o fim deles. Mas ao chegar no fim deles é a evolução tonal da melodia que obriga a recomeçar outra vez. E isso leva a multiplicar infindavelmente a pequena frase da cantoria, e tirar pois, fisiopsiquicamente falando, todo o poder hipnótico que ela tem" (Andrade, s/d, p. 43-44).
} 
O ritmo é para Mário o mais básico dos parâmetros musicais, e a solução do problema rítmico na música popular brasileira figura de alguma maneira a tensão dilemática da nossa formação social, aquele "sentimento dos contrários" que marca a dinâmica específica da experiência cultural num país colonial como o Brasil, tão bem sintetizado por Antonio Candido como uma dialética rarefeita entre localismo e cosmopolitismo, entre o não ser e o ser outro: "o brasileiro não pode deixar de viver pendurado no Ocidente e ele deve tentar não viver pendurado no Ocidente. Ele tem que tentar fazer uma cultura dele, mas a cultura que ele pode fazer é uma cultura pendurada no Ocidente (...) Nós somos o outro e o outro é necessário para a identidade do mesmo" (Candido, 1980, p. 4 e 9). "Daí a imundície de contrastes que somos", diria Mário de Andrade, a qual nos impossibilitaria de "compreender a alma-brasil por síntese" (Andrade, 1974: 8).7 Em outras palavras, os ritmos populares como que cifram as contradições culturais do processo de colonização, engendrado no conflito entre os tempos divergentes da música europeia - o tempo da mensuração, do compasso, do ritmo demarcado pelos retornos regulares, em suma, da periodicidade quadrada - e da música indígena-africana - o tempo de uma rítmica fraseológica, prosódica, caracterizada pela expansão em aberto e por uma periodicidade continuamente variada. A música indígena e negra se caracteriza não pela subdivisão do compasso, mas pela adição de tempos - tempo afirmativo, que se realimenta na variação. Segundo Mário, a rítmica musical brasileira traduz musical e metaforicamente essa nossa dualidade constitutiva, ao criar um "jeito fantasista de ritmar" que, , produzindo "um compromisso sutil entre o recitativo e o canto estrófico", vai dançando as palavras livre e variadamente por entre as barras do compasso.

\footnotetext{
${ }^{7}$ Não à toa, num concurso promovido pela revista Rural para escolha da rainha das flores brasileiras, Mário dá seu voto à Vitória Régia amazônica: "Mistura de mistérios, dualidade interrogativa de coisas sublimes e coisas medonhas, grandeza aparente, dificuldade enorme, o melhor e o pior ao mesmo tempo, calma, tristonha, ofensiva, é impossível a gente ignorar que nação representa essa flor...” (Andrade, 1976: 184).
} 
As características desse ritmo se fazem presentes também na estrutura das próprias danças dramáticas, que procedem pela aposição e pela variação: formam-nas como que um palimpsesto que guarda a co-incidência de tempos culturais/corporais divergentes (Wisnik, 1979, p. 140). O ritmo que essa música inventa - elaborando essa complexa superposição de tempos díspares em que as recorrências são sempre sutilmente deslocadas - nos introduz na ambiguidade que surpreendemos em Macunaíma como processo construtivo: a tensão de uma narrativa que busca a resolução (enfileirando-se assim na ordem do tempo progressivo) e burla, escamoteia e adia a necessidade dessa resolução, prolongando-se de maneira polimorfa (o que a lança no plano de um tempo regressivo) (Wisnik, 1979, p. 140; Souza, 2005).

As tendências naturais estão em luta franca contra a influência européia e se dessa luta provêm muitos estragos na melódica nordestina, se é provável que com o progresso e a Civilização (!) o tonalismo harmônico europeu acabará vencendo e será uma pena amaldiçoada, o nordestino mostra nos seus processos populares e de fazer música o quanto é avesso à harmonia. Por outro lado muitas vezes no coro os cantadores executam variantes melódicas simultaneamente, variantes que às vezes chocam harmonicamente pois dão segundas e outros intervalos harmônicos chamados de dissonantes. As linhas se juntam assim chocantes numa polifonia perfeitamente horizontal, ninguém dando mostras de desagrado por causa dessas dissonâncias. E quais são os instrumentos que acompanham essas melodias? Na infinita maioria das vezes instrumentos de percussão, dando ruídos, puítas, ganzás, bombos, maracás, recos, executando ritmos e isentos de harmonia, livres de harmonização. Assim a música permanece exclusivamente rítmico- 
melódica. [...] E na pancada do ganzá vai construindo suas linhas raras, variadas, modais, isentas de prisão acordal e tonal. ${ }^{8}$

A não submissão do ritmo à regularidade do compasso constitui justamente, nas danças coreográficas, a força dinamogênica que, ao empurrar os sons da linha pra fora do tempo batido, sugestionam o corpo a remeleixos e dengues. Naturalmente, Mário surpreendia na síncopa uma potência se não subversiva, ao menos neutralizadora, da métrica regular do compasso. “A síncopa europeia é uma consequência prática das especulações obtusas dos franco-flamengos e madrigalistas. Na América o conceito de síncopa surgiu doutra necessidade que por mais fisiológica e popular, se poderá chamar de mais essencial. [...] Na América a síncopa não provém da síncopa européia. É uma realização imediata e espontânea das nossas maneiras de dançar, mais sensuais, provinda do clima talvez, e do amolecimento fisiológico das raças que se caldearam pra nos formar e formaram também o remeleixo, o requebro, o dengue. É o movimento dengoso do corpo na dança que deformou a rítmica da polca primeiramente na rítmica da habanera e em seguida no do maxixe" (Andrade, 1989, p. 476).

Como uma espécie de dobra ou "espaço que medeia entre dois tempos" (Monteiro, 2014, mimeo), a síncopa se revela metafórica e musicalmente na transformação da polca em maxixe, através dos deslocamentos rítmicos - com a decantação da própria síncopa e seus efeitos contramétricos e balançantes - enlaçados à africanização abrasileirada desse exemplar de dança européia (portanto, importada) de salão, sincreticamente misturada à música negra dos escravos. O abrasileiramento operado na sincopação da polca - pela acentuação em pontos deslocados do tempo, fora dos lugares tônicos do compasso binário, fixados originariamente no padrão importado

8 “Melódica Anti-harmônica”, Melodia: nota de pesquisa, caixa 65. Manuscritos Mário de Andrade, IEB/USP.

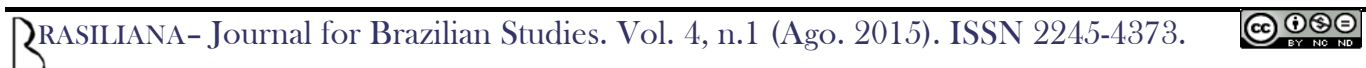


(ou em pontos não tônicos da métrica regular do compasso) - produzem um efeito oscilante entre dois pulsos simultâneos e defasados. Neste sentido, Mário de Andrade via a rítmica brasileira como uma resultante híbrida, da combinação original da quadratura métrica da música européia, que procede pela subdivisão do compasso, com uma rítmica fraseológica apoiada em irregularidades internas e que procede pela adição indeterminada de tempos, como as músicas africanas e indígenas.

O conceito de síncope aparece então como descompasso entre a partitura, feita para formalizar a harmonia, e uma polirritmia que não se subordina a ela sem deixar um resto. Trata-se, como sugere mais uma vez Wisnik, de uma dialética rítmica que se baseia no balanceio entre uma ordem e sua contra-ordem acentual, sustentadas num mesmo movimento. Essa dialética põe em movimento um "negaceio estrutural [...], cheio de acenos e recuos, de promessas em aberto, de objetos chamativos e escapadiços, conduzidos numa cadência aliciante" (Wisnik, 2003, p. 36). Desta maneira, Mário evita definir esses processos rítmicos a partir do ponto de vista unilateral da música européia, reduzindo-os a desvios da norma do compasso; antes, sua lógica rítmica é eminentemente ambivalente, não se confinando à medida regular do compasso, baseada na subdivisão e replicação de células regulares. A rítmica brasileira seria - parodiando título célebre no debate sobre a aclimatação das ideias - "nacional por adição", isto é, procederia por meio da adição simultânea de células desiguais, pares e ímpares, produzindo múltiplas referências de tempo e contratempo - e, logo, fases e defasagens que resultaria naquilo que a etnomusicologia denomina contrametricidade (Sandroni, 2001). Assim, opera-se uma abertura na quadratura, que cede lugar a uma outra lógica, fundada na dialética entre duas ordens de acentuação simultâneas que a rítmica afroeuropeia brasileira aciona: a do compasso binário, tensionada pela contrametricidade, e a da adição combinada de células pares e ímpares, que se abrigam e se subdividem, no entanto, no interior do compasso (Ibidem). 


\section{Conclusões}

Como procuramos mostrar brevemente, a improvisação, a quebra da métrica regular do compasso europeia e a recalcitrância aos parâmetros do temperamento moderno divisadas de maneira não essencializada nos processos de criação da música popular por Mário de Andrade parecem apontar para direções e graus diferentes do processo de racionalização musical, que desafiam o sentido da calculabilidade, do controle e da previsibilidade assumido pela música ocidental. Se por um lado o campo metafórico que assim se abre sinaliza para lógicas alternativas e contra-hegemônicas à marcha civilizatória progressiva do Ocidente, por outro lado, ela permite evitar o que há de mais terrível na perspectiva sintética da "metafísica da identidade", a saber, a assimilação ou supressão da alteridade, em proveito da autoafirmação identitária. Esta que é a história mesma dos recorrentes mas variados colonialismos e neocolonialismos que se desenvolveram ao longo da história ocidental.

Antes de finalizar, vale abrir aqui um parêntese e assinalar que esta potência identificada nos processos da música popular brasileira parece encontrar correspondência, na crítica musical de Mário de Andrade, na valorização da espontaneidade da interpretação. Ela é ressaltada, por exemplo, na maneira de cantar de Raquel Bastos, pois, "se às vezes discrepa um tanto da maneira tradicional com que certos autores são interpretados, traz em compensação um elemento novo, uma graça ignorada e uma perpétua surpresa" (Andrade, 1994: p. 104). Essa capacidade de introduzir o novo, de gerar surpresa permanente é fundamental para Mário de Andrade, porque, por um lado, transforma a interpretação num ato também de criação e, por outro, mantem a música unida à vida, vista como seu elemento primeiro de inspiração. União sem a qual a música deixa de ser "uma força de expressão humana, 
não mais uma manifestação da coletividade, da raça, do povo, do indivíduo, mas uma coisa gelada, de cálculo, uma música dos músicos" (Ibidem). Assim, a espontaneidade de interpretação torna possível romper com o que chama de "fetichismo" do "estilo" acalentado por uma pletora de músicos intérpretes à época, no qual os autores eram "encerrados, deformados e mumificados numa tradição falsa" que fixava uma maneira estereotipada de interpretação da obra. Na mesma direção, vão os elogios de Mário ao violinista Mischa Elman pela "humanidade" das suas intepretações, que não elevam "os seus ouvintes para os seus humanos da perfeição estética", mas lhes abrem os olhos "para esta apaixonada e torturada alma humana" (Idem, p. 199). Na crítica seguinte, publicada no mesmo Diário de S. Paulo em 27 de junho de 1934, Mário aponta o pianista virtuose Cláudio Arrau como "polo oposto ao de Mischa Elman". Nele a virtuosidade seria um "elemento independente da arte propriamente, valendo por si mesma, e consistindo na possessão malabarística" (Idem, p. 201). Ele não é capaz de fazer o ouvinte esquecer a arte e a técnica, de modo que Mário diz sair do espetáculo "mais admirado que comovido, mais encantado que amando", sem em nenhum momento esquecer que "a arte é o 'jogo', a brincadeira dos estetas", como que preso à contemplação da beleza. Assim, como a racionalidade instrumental no Ocidente, poderíamos dizer, a virtuosidade de Cláudio Arrau "sorrateiramente se transformou numa invisível finalidade" (Ibidem). Portanto, para Mário, a interpretação de uma peça musical jamais poderá assumir um sentido unívoco sem violentar sua liberdade e fazer tábula rasa da multiplicidade de sentidos que ela pode abrigar. E por isso mesmo a crítica, a fim de ajuizar essas interpretações, deve permanecer, em sua visão, como uma atividade aberta, eminentemente exploratória e inconclusa. Não ambiciona alcançar uma posição supostamente privilegiada, dotada de isenção, e mostra-se avessa ao que Mário chamava de "valor-eternismo": a conversão das obras num absoluto, cujo sentido metafísico, formulado por valores estáveis e puros, se projetaria fora do tempo. O que se 
denomina "estilo", portanto, se faz de contrastes, de evoluções que acotovelam involuções. E a crítica, neste passo, deve acolher a dúvida e a surpresa, e através da polifonia e do contraponto, como a música, ser capaz de ritmar a repetição e a diferença, o mesmo e o diverso, o contínuo e o descontínuo, mostrando, enfim, o humano, sempre ondulante, sob os caprichos da forma, transfigurado nas artes.

Por último, valorizando um gesto heurístico mais amplo de abertura (e inacabamento) na obra de Mário de Andrade, para quem nem tudo deve se fechar num sentido unívoco, por assim dizer gostaria de terminar este texto na sensível. Sabe-se que Mário considerava a melodia o elemento formal mais importante para a identificação das tendências e constâncias da música popular brasileira. Entre essas tendências, justamente a terminação na sensível gera, ao contrário da forma convencional dos Lieder alemães (na qual o final-suspensivo é apenas um adiamento do final-conclusivo), uma tensão harmônica que deixa, no público ouvinte, a sensação física de uma música que não acaba definitivamente, perpetuando, assim, um desejo de continuação. Diz Mário:

Certos cocos como o Meu Baraio 2 Ouro (Chico Antônio) repetidos 15 minutos em vez de engendrarem na gente o exaspero, a revolta contra a monotonia, é inconcebível o efeito delicioso de quentura amolecida sossego sem previsar, descanso eterno, paz infindável que dão. $\mathrm{O}$ cantador exerce uma verdadeira encantação sobre o ouvinte popular e... sobre mim. E constato que a repetição da frase melódica é que convence. Daí a precisão de evitar na linha o efeito cadencial que termina duma vez. Daí a repugnância do brasileiro pela tônica. E daí a verdadeira 
atração pela sensível terminando o período e obrigando a iniciar outro que nos dê a esperança de acabar. ${ }^{9}$

À aversão ao final cadencial terminado na tônica, característica popular, poderíamos dizer que corresponde a recusa do apolíneo conclusivo e racional, e a terminação suspensiva, exilada na sensível, ao imponderável do dionisismo (Teixeira, 2007, p. 31). O exame da questão da imponderabilidade da vida social a longo prazo traz conseqüências ameaçadoras para um mundo que acredita no cálculo, na racionalidade e na previsão, exclamando-nos o fato de que a relação de causalidade não é nem infalível nem absolutamente correta. Marianne Weber, em sua biografia do marido, relata-nos que este teria se comovido profundamente com os destinos humanos que lhe tocavam o coração, sobretudo por ter apreendido que uma idéia podia se desenvolver em oposição ao seu sentido inicial, terminando por destruir-se a si mesma. Deixo então o leitor com uma última citação de Mário sobre a qual talvez valha a pena meditar: "somos verdadeiramente uma sétima de dominante, esta dissonância, esta insatisfação, este anseio insofrido, sempre em busca dum acorde perfeito, duma resolução final que aplaque duma vez as tristuras do mundo" (Andrade, 1980, p. 48).

\section{Referências bibliográficas}

Alvarenga, Oneyda. Mário de Andrade, um pouco. Rio de Janeiro: José Olympio, 1974.

\footnotetext{
9 “Melódica/Terminação na sensível: n’. 39 dos Congos/ nº 45 dos Congos”. Caixa 65: melodia. Manuscritos Mário de Andrade. IEB-USP.
} 
Andrade, Mário de. Ensaio sobre a música brasileira. 3.ed. São Paulo/Brasilia: Martins/INL, 1972.

. Música, doce música. São Paulo/Brasília: Martins/MEC, 1976.

Os cocos. São Paulo/Brasília: Duas Cidades/INL, 1984.

. Dicionário musical brasileiro. Belo Horizonte/ Brasília/ São Paulo: Itatiaia/ MinC/ IEB-Edusp, 1989. . Música de feitiçaria no Brasil. São Paulo: Martins, s/d.

Fuente, Eduardo de la. Twentieth century music and the question of modernity. New York e Londres: Routledge, 2011.

Monteiro, Pedro Meira. Por que ela, agora, aqui? Trabalho apresentado no XII Congresso Internacional da Associação de Estudos Brasileiros (BRASA), 20-23 de agosto, King's College, Londres, 2014.

Rezende, Gabriel Sampaio Souza Lima. Um universo de pensamentos musicais na escrivaninha de um sociólogo: Max Weber e "Os fundamentos racionais e sociológicos da música. Dissertação de mestrado. Unicamp, 2010.

Sandroni, Carlos. Feitiço decente. Rio de Janeiro: Zahar, 2001.

Schorske, Carl E. Viena fin-de-siècle: política e cultura. Tradução de Denise Bottman. São Paulo: Companhia das Letras, 1988.

Weber, Max. Os fundamentos racionais e sociológicos da música. São Paulo: Edusp, 1995.

Wisnik, José Miguel. Dança Dramática (poesia/música brasileira). Tese de doutoramento. FFLCH-USP, 1979. 
Machado maxixe: o caso Pestana. In: Teresa. Revista de Literatura Brasileira, São Paulo, FFLCH/USP, n. 4/5, p. 13-79, 2003.

Teixeira, Maurício de Carvalho. Torneios Melódicos: poesia cantada em Mário de Andrade. Tese de doutorado. Departamento de Letras Clássicas e Vernáculas, Faculdade de Filosofia, Letras e Ciências Humanas, Universidade de São Paulo, 2007.

Toni, Flávia Camargo. REVISTA USP, São Paulo, n.77, p. 24-33, março/maio, 2008.

Travassos, Elizabeth. Os mandarins milagrosos. Rio de Janeiro: Jorge Zahar/Funarte, 1997. 